\title{
Phytopreventive antihypercholesterolmic and antilipidemic perspectives of zedoary (Curcuma Zedoaria Roscoe.) herbal tea
}

\author{
Sara Tariq ${ }^{1}$, Muhammad Imran², Zarina Mushtaq ${ }^{2^{*}}$ and Nosheen Asghar ${ }^{1}$
}

\begin{abstract}
Background: Metabolic syndrome is an increasingly prevalent problem, not only in industrialized developed countries, but in developing countries as well. The modern healthcare to reduce the dysfunction of metabolic syndrome is burdened with great problems of unsafe medicines and certain degree of side effects. Medicinal plants and derived component products are becoming increasingly popular in modern society as natural alternatives to synthetic multiple drugs for the treatment of hypercholesterolemia and hypertriglyceridemia. The present research work was carried out to evaluate the zedoary (Curcuma zedoaria Roscoe.) herbal tea (ZHT) for antihypercholestrolemic and antilipidemic perspectives in discerning consumers.
\end{abstract}

Methods: Zedoary rhizome dried powder (ZRDP) after proximate composition analysis was used to prepared ZHT samples as $T_{1}\left(500 \mathrm{mg}\right.$ ZRDP), $\mathrm{T}_{2}$ (1 $\mathrm{g}$ ZRDP) and $\mathrm{T}_{3}(1.5 \mathrm{~g}$ ZRDP) in $200 \mathrm{~mL}$ boiling water for 5 minutes, respectively. ZHT samples were characterized for total phenolic compounds (TPC), DPPH inhibition, total flavonoids, color tonality ( $\mathrm{L}^{*}, \mathrm{a}^{*}$ and $\mathrm{b}^{*}$ value), $\mathrm{pH}$, acidity, total soluble solids (TSS) and sensory acceptance. Thirty mildhypercholestrolemic male human volunteers were randomly allocated to three groups $\left(G_{1}, G_{2}\right.$ and $\left.G_{3}\right)$ and each group consisting of 10 mild-hypercholestrolemic male human subjects. The volunteers were assigned ZHT samples for consecutive two months. The blood drawn for day 0, day 30 and day 60 after an overnight $12 \mathrm{~h}$ fast was analyzed for serum parameters such as total cholesterol (TC), high-density lipoprotein cholesterol (HDL-cholesterol), low-density lipoprotein cholesterol (LDL-cholesterol) and triglycerides (TG) concentration.

Results: The ZRDP possessed abundantly the crude protein (13.5 $\pm 0.68 \%)$, total dietary fiber $(21.86 \pm 0.71 \%)$, acid detergent fiber (13.22 $\pm 0.44 \%)$, neutral detergent fiber (18.68 $\pm 0.53 \%)$ and mineral contents. Highest TPC, DPPH inhibition and total flavonoids values were observed $9.74 \pm 0.64$ (mg GAE/g DW), $47.28 \pm 1.62$ (\%) and $17.12 \pm 0.75$ (QE mg/g), respectively in $T_{3} . L^{*}$ value was significantly $(p \leq 0.05)$ low for $T_{3}$ samples. In contrast, $a^{*}$ value and $b^{*}$ value was significantly $(p \leq 0.05)$ higher for $T_{3}$ when compared with $T_{1}$ and $T_{2} \cdot T_{3}$ samples showed lower $p H$ (5.13 \pm $0.13)$ and higher acidity $(0.25 \pm 0.08)$ values than $T_{1}(5.64 \pm 0.25,0.17 \pm 0.05)$ and $T_{2}(5.42 \pm 0.21,0.21 \pm 0.06)$, respectively. Similarly, an increasing trend in TSS contents was observed. Sensory scores assigned to color, flavor, aroma and overall acceptability attributes varied in a quite narrow range for all ZHT samples. The lowest evaluation scores were recorded for $T_{3}$ samples. The $G_{3}$ showed the more reduction in body weight and BMI during efficacy study as compared to $G_{1}$ and $G_{2}$. The decrease in serum $T C$ for $G_{1}, G_{2}$ and $G_{3}$ on day 60 was observed $9 \%, 14 \%$ and $17 \%$, respectively when compared with reference value at day 0 . The consumption of $\mathrm{T}_{3}$ resulted in significant increase (6.8\%) of HDL-cholesterol after two months. A trend in decrease of serum LDL-cholesterol (5.6 \%) and TG $(12.5 \%)$ was also observed after consumption of $\mathrm{T}_{3}$ at day 60.

(Continued on next page)

\footnotetext{
*Correspondence: zee_ft@hotmail.com

${ }^{2}$ Institute of Home and Food Sciences, Faculty of Science and Technology,

Government College University, Faisalabad, Pakistan

Full list of author information is available at the end of the article
} 
(Continued from previous page)

Conclusions: The results of the present study conclude that the strong phenolic contents and radical scavenging activity of zedoary rhizome have protective role against hypercholesterolemic and lipidemic conditions.

Keywords: Curcuma zedoaria, water extract, herbal tea, TPC, DPPH, hypercholesterolemia, hyperlipidemia

\section{Background}

The appropriate treatment of different components of metabolic syndrome such as hypercholesterolemia and hypertriglyceridemia require the prescription of synthetic multiple drugs to prevent or to lessen the risk of cardiovascular morbidity and mortality. However, the present drugs available for the treatment of metabolic syndrome are few in number, limited in efficacy and have certain degree of side effects. The results of many investigations clearly showed that the inappropriate medication can accelerate the dysfunction of metabolic syndrome and weight gain in susceptible people. In such situation, there should be a clear preference for natural functional foods as alternative medicines which not only lower blood cholesterol but also reduce plasma triglycerides in metabolic syndrome suspected subjects. Plants are considered as a rich source of phytochemicals and many current chemotherapeutic drugs still relies greatly on crude plants, their products and herbal extracts to cure human ailments in developing countries [1]. Family Zingiberaceae consisting of about 1400 species and 47 genera has been used in traditional medicine for centuries [2]. Curcuma zedoaria also known as white turmeric, kachur and zedoary is a continuing herb belongs to family Zingiberaceae which is cultivated all over Asia. The zedoary plant with about $1.2 \mathrm{~m}$ height has vertical aerial stems (pseudostems) and straight underground stems known as rhizomes. The zedoary rhizomes color ranges from pale yellow to bright yellow and become brown on age maturity. Dried rhizomes have musky odor with slight camphor smell and a bitter pungent aftertaste. Traditionally, zedoary is being used as antiinflammatory, carminative, antitumor, gastrointestinal stimulant, antiulcer, stomachic, antiallergic, diuretic, hepatoprotective, antinociceptive, demulcent, expectorant, rubefacient and antimicrobial [3-7].

It is well known that the medicinal properties of zedoary depend upon the presence of active chemical components such as terpenoids, flavonoids, phenylpropanoids and sesquiterpenes. Zedoary rhizomes consist of number of bioactive compounds namely zederone, curzerenone, 1,3hydroxygermacrone, epicurzerenone, curcumol, zedoarol, curcolone, ar-turmerone, zedoarondiol, isocurcumenol, furanodiene, curdione, curcumenol, curcumanolide A, zingiberene, procurcumenol, curzeone, curcumin, curcumenone, curcumanolide B, dehydrocurdione, curzerene, $\beta$-turmerone and curcumadiol. The rhizome volatile oil possessed major components as curzerenone, germacrone, camphor and curcumenol $[5,8,9]$. Most of the studies investigating the effects of zedoary and its components on health involve animal models. There are still very few studies done to determine whether the positive results seen in animal studies extend to humans. However, dried zedoary powder has been widely accepted as spices in many conventional recipes. Moreover, zedoary extract has been supplemented in different food products due to presence of potential antioxidant properties [10]. Since plants of family Zingiberaceae are well thought-out safe for human use, therefore, these rhizomes can be outstanding candidates for development of new chemotherapeutics and nutraceutical actions. Therefore, keeping in view the medicinal potential and bioactive compounds present in zedoary, the present project was designed to use the zedoary rhizome dry powder (ZRDP) in combating the mild-hypercholesterolemia condition in volunteer human subjects. The main mandate of this study was characterization of ZRDP and its herbal tea (ZHT) for chemical constituents, sensory acceptability, antihypercholestrolemic and antilipidemic perspectives.

\section{Methods}

\section{Preparation of raw material}

Zedoary (Curcuma zedoaria Roscoe.) rhizomes, purchased from local super market, were washed to remove the dirt, dust and foreign materials adhered to samples surface. Then, the raw material was dried by using air forced draft oven (Model: DO-1-30/02, PCSIR, Pakistan). The dried material was grounded to fine powder by using a small laboratory grinder (Panasonic, Japan, Model MJ-W176P) and passed through a sieve for further refining. After preparation of powder, it was packed in air-tight plastic jars and stored at $5 \pm 1{ }^{\circ} \mathrm{C}$ until further analysis.

\section{Chemical characterization of raw material}

Moisture content of zedoary rhizome samples was analyzed by using air forced draft oven. The samples were dried at $105 \pm 5{ }^{\circ} \mathrm{C}$ to constant weight and calculations were made (Method No. 44-15A) [11]. For determination of crude protein in samples, nitrogen percentage was estimated through Kjeltech Apparatus (Model: D40599, Behr Labor Technik, GmbH-Germany). The 
protein was calculated by multiplying percent nitrogen with conversion factor (Method No. 990.03) [12]. Oven dried samples were estimated for crude fat by using Soxtec System (Model: H-2 1045 Extraction Unit, Hoganas, Sweden). $5 \mathrm{~g}$ of sample was taken for extraction of crude fat with petroleum ether. After extraction, left over residue was dried until constant weight (Method No. 30-10) [11]. After extraction of fat, samples were studied for crude fiber through Labconco Fibertech (Labconco Corporation Kansas, USA). The digestion of $2 \mathrm{~g}$ fat free samples was carried out with $1.25 \% \mathrm{H}_{2} \mathrm{SO}_{4}$ and $1.25 \% \mathrm{NaOH}$. The residue was dried at $130{ }^{\circ} \mathrm{C}$ for 2 hours and weighed followed by ignition at $550 \pm 15{ }^{\circ} \mathrm{C}$ and then cooled for further calculations (Method No. 978.10) [12]. Samples were taken in preweighed crucible for ash content determination and charred on burner till no fumes before incineration in the Muffle Furnace (MF-1/02, PCSIR, Lahore, Pakistan) to obtain white grayish color of residue (Method No. 08-01) [11]. NFE was calculated according to expression: NFE $(\%)=100-($ Moisture $\%+$ Crude protein $\%+$ Crude fat $\%+$ Crude fiber $\%+$ Total ash $\%)$. Total dietary fiber (Method No. 985.29) [12], acid detergent fiber (Method No. 973.18) [12] and neutral detergent fiber [13] contents were analyzed by employing the Megazyme Assay Kit (Megazyme International, Ireland Ltd; Wicklow, Ireland). Concentration of mineral contents was determined by running the diluted ZRDP samples through Atomic Absorption Spectrophotometer (Model: Varian AA-240, Victoria, Australia).

\section{Development and characterization of ZHT}

Preliminary some trials were conducted for the development of ZHT product in laboratory. The purpose was to obtain an acceptable quality product for consumers. After fixing the recipe, different treatments of ZHT were made and evaluated for various quality characteristics. Functional ZHT samples evaluated in the experiments were prepared from boiling of ZRDP as $T_{1}(500 \mathrm{mg}$ ZRDP), $\mathrm{T}_{2}(1 \mathrm{~g} Z \mathrm{ZRDP})$ and $\mathrm{T}_{3}(1.5 \mathrm{~g} \mathrm{ZRDP})$ in $200 \mathrm{~mL}$ boiling water for 5 minutes, and strain, respectively. Estimation of total phenolic contents (TPC) was carried out using Folin-Ciocalteu method as described by Singleton et al. [14]. The ability of ZHT samples to scavenge the stable free radical DPPH and convert it into Diphenyl picryl hydrazine was determined by the method described by Mensor et al. [15]. Total flavonoids were estimated using the method of Ordon-ez et al. [16]. Color tonality of product samples was observed by the method of Rocha et al. [17]. For color hue, L* (lightness), a* (-a greenness, $+a$ redness) and $b^{*}$ ( $-b$ blueness, $+b$ yellowness) values were recorded using CIE-Lab Color Meter (CIELAB SPACE, Color Tec-PCM, USA). The pH of ZHT samples was measured through electronic digital
$\mathrm{pH}$ meter (Inolab WTW Series 720). Acidity in ZHT samples was determined by the Method No. 947.05 given in AOAC [12]. The total soluble solids (TSS) in the sample were determined with the help of an Abbe type Refractometer and the values were expressed as degree Brix $\left({ }^{\circ} \mathrm{B}\right)$. A temperature correction was also applied when the temperature was above or below $25^{\circ} \mathrm{C}$.

\section{Sensory evaluation of ZHT product}

The sensory evaluation of ZHT samples was carried out in an adequate room $\left(25{ }^{\circ} \mathrm{C}\right)$ according to the instructions given by Meilgaard et al. [18]. Fourteen judges panel consisting of experienced and untrained panelists was selected for assessing the samples. Each judge gave written informed consent after explanation of risks and benefits of participation prior to the study. Each panelist was offered samples randomly from experimental treatments placed in closed plastic cups labeled with three secret digit codes. Prior to evaluation, the panelists were provided informative instructions and brief definitions of attributes such as color, flavor, aroma and overall acceptability. Each panelist was asked to list their preference on a 9-point Hedonic scale (where $1=$ dislike extremely and $9=$ like extremely).

\section{Human subjects, ZHT treatments and serum lipid profile assay}

Eligibility in the human study program required willingness and ability to adhere with research program protocol. The study program was designed after the review of ethical guidelines set by parent institute and earlier research studies conducted for evaluation of herbal tea. Thirty mild-hypercholestrolemic male human volunteers ranging in age from 25-40 years old having no diagnosed heart disease were provided a hard copy of informed consent form after expressed an interest as potential participants in the program. They were randomly allocated to three groups $\left(G_{1}, G_{2}\right.$ and $\left.G_{3}\right)$. Each group was consisting of 1o mild-hypercholestrolemic male human subjects. The participants were asked to complete surveys which include questions about dietary intake, physical activities, stress management and any life threatening illness. At the end of survey, the participants were asked to make an appointment for physical assessment on baseline study period. The complete data of participant regarding contact information and method of recruitment was recorded. The participants were given free hand for refuse or answer any questions that were part of the survey. All the information that participant provide, either on paper or in person, was kept confidential. The volunteers were assigned tea bag samples containing $500 \mathrm{mg}, 1 \mathrm{~g}$ and $1.5 \mathrm{~g}$ ZRDP for consecutive two months consumption. The volunteers were advised to prepare the $\mathrm{ZHT}$ according to the set procedure and 
orally consume the ZHT in standard cup twice daily between the meals. The volunteers were further advised to avoid consumption of green or black tea and continue to take routine self-selected diet and perform exercise. The blood drawn for day 0, day 30 and day 60 after an overnight $12 \mathrm{~h}$ fast was analyzed for serum parameters. The total cholesterol (TC) was determined by liquid cholesterol CHOD-POP method [19]. The high-density lipoprotein cholesterol (HDL-cholesterol) concentration was analyzed by using HDL-cholesterol kits [20]. Lowdensity lipoprotein cholesterol (LDL-cholesterol) concentration was assay by following the mathematical expression described by McNamara et al. [21]. The triglycerides (TG) concentration was determined by liquid triglycerides GPO-PAP method [22]. Aspartate aminotransferase (AST) and Alanine aminotransferase (ALT) were determined to assess liver function during the entire study. AST and ALT were measured by dinitrophenylehydrazene (DNPH) method following the procedure of Basuny [23].

\section{Statistical analysis}

The data for chemical characterization of ZRDP and ZHT samples was subjected to statistical analysis to determine the level of significance by using the software package (Minitab ${ }^{\circ}$ Ver. 8.2.0). The average of the three replicates was reported as the measured value with standard deviation. The Duncan's multiple range (DMR) test was used to estimate the level of significance that existed between the mean values. The effect analysis of ZHT on serum lipid profile of mild-hypercholestrolemic human subjects was carried out in triplicate and calculated the significant differences among means at a probability level of $5 \%$ [24].

\section{Results and discussion}

Physico-chemical composition and sensory acceptability of ZRDP and ZHT

The mean values for the moisture, crude protein, crude fat, crude fiber, ash and NFE contents of ZRDP were found $10.74 \pm 0.52(\mathrm{~g} / 100 \mathrm{~g} \mathrm{DM}), 13.5 \pm 0.68(\mathrm{~g} / 100 \mathrm{~g}$
DM), $3.64 \pm 0.24(\mathrm{~g} / 100 \mathrm{~g} \mathrm{DM}), 2.32 \pm 0.18(\mathrm{~g} / 100 \mathrm{~g}$ $\mathrm{DM}), 6.21 \pm 0.41(\mathrm{~g} / 100 \mathrm{~g} \mathrm{DM})$ and $63.58 \pm 0.66(\mathrm{~g} / 100 \mathrm{~g}$ $\mathrm{DM})$, respectively. ZRDP possessed total dietary fiber $(21.86 \pm 0.71 \mathrm{~g} / 100 \mathrm{~g} D W)$, acid detergent fiber $(13.22 \pm$ $0.44 \mathrm{~g} / 100 \mathrm{~g} \mathrm{DW})$ and neutral detergent fiber (18.68 \pm $0.53 \mathrm{~g} / 100 \mathrm{~g} \mathrm{DW}$ ) contents, respectively. The minerals calcium, copper, zinc, magnesium, potassium, phosphorous, sodium and iron were ranged $1.92 \pm 0.12 \mathrm{~g} / \mathrm{kg} D M$, $6.38 \pm 0.14 \mathrm{mg} / \mathrm{kg} \mathrm{DM}, 104.5 \pm 1.38 \mathrm{mg} / \mathrm{kg} \mathrm{DM}, 2.42 \pm$ $0.11 \mathrm{~g} / \mathrm{kg} \mathrm{DM}, 22.65 \pm 0.26 \mathrm{~g} / \mathrm{kg} \mathrm{DM}, 3.10 \pm 0.13 \mathrm{~g} / \mathrm{kg}$ $\mathrm{DM}, 0.28 \pm 0.09 \mathrm{~g} / \mathrm{kg} \mathrm{DM}$ and $312.45 \pm 2.88 \mathrm{mg} / \mathrm{kg} \mathrm{DM}$, respectively in ZRDP samples. There is very scant information available regarding the chemical composition of the true zedoary rhizome in the literature during the past decade [25]. Zedoary (bulb) and zedoary (finger) possessed the moisture contents $7.30 \pm 0.45 \%$ and 6.28 $\pm 0.08 \%$, respectively [26]. In another study, moisture content in zedoary rhizome samples was noted $5.35 \pm$ $0.94 \%$ [27]. Proximate composition showed that the rhizomes of zedoary contained $14.85 \%$ protein on moisture free basis while organic and inorganic phosphorus and calcium contents of rhizomes were found very high in concentration [28]. Total ash content in rhizome was found $7.5 \pm 0.16 \%$ [27] while other study concluded that the zedoary rhizome yields not more than $6.64 \%$ percent of ash [29]. The changes in proximate composition in comparison to earlier reported values may be due to climate conditions, ripening stages, soil type, soil condition and irrigation regime [30,31]. Other differences in concentration could be explained by adulteration after harvest, processing or transport [32].

The significant results of ZHT samples analyzed for physico-chemical analysis (total phenolic contents, $\mathrm{DPPH}$ inhibition, total flavonoids, color tonality, $\mathrm{pH}$, acidity and total soluble sugars) have been presented in Table 1. Results indicate that the total phenolic, DPPH inhibition and total flavonoids were gradually increased on the incorporation of ZRDP from $0.5 \mathrm{mg}$ to $1.5 \mathrm{~g}$ in ZHT boiling water. Maximum concentration for these parameters was observed 9.74 \pm 0.64 (mg GAE/g DW), $47.28 \pm 1.62(\%)$ and $17.12 \pm 0.75(\mathrm{QE} \mathrm{mg/g})$, respectively

Table 1 Physico-chemical composition of zedoary herbal tea

\begin{tabular}{|c|c|c|c|c|c|c|c|c|c|}
\hline \multirow[t]{3}{*}{ Treatments } & \multicolumn{9}{|c|}{ Physico-chemical components } \\
\hline & \multirow{2}{*}{$\begin{array}{l}\text { TPC } \\
\text { (mg GAE/g DW) }\end{array}$} & \multirow{2}{*}{$\begin{array}{l}\text { DPPH } \\
\text { Inhibition (\%) }\end{array}$} & \multirow{2}{*}{$\begin{array}{l}\text { TFC } \\
(\mathrm{QE} \text { mg/g) }\end{array}$} & \multicolumn{3}{|l|}{ Color tonality } & \multirow[t]{2}{*}{$\mathrm{pH}$} & \multirow[t]{2}{*}{ acidity } & \multirow[t]{2}{*}{ TSS } \\
\hline & & & & $L^{*}$ value & $a^{*}$ value & $b^{*}$ value & & & \\
\hline $\mathrm{T}_{1}$ & $5.90 \pm 0.42^{c}$ & $36.57 \pm 1.24^{c}$ & $10.76 \pm 0.58^{c}$ & $22.36 \pm 1.52^{a}$ & $7.78 \pm 0.51^{c}$ & $5.75 \pm 0.23^{c}$ & $5.64 \pm 0.25^{a}$ & $0.17 \pm 0.05^{c}$ & $2.13 \pm 0.15^{c}$ \\
\hline $\mathrm{T}_{2}$ & $7.35 \pm 0.56^{b}$ & $42.28 \pm 1.45^{b}$ & $14.39 \pm 0.66^{b}$ & $21.50 \pm 1.36^{b}$ & $8.98 \pm 0.55^{b}$ & $6.99 \pm 0.35^{b}$ & $5.42 \pm 0.21^{b}$ & $0.21 \pm 0.06^{b}$ & $3.86 \pm 0.21^{b}$ \\
\hline$T_{3}$ & $9.74 \pm 0.64^{\mathrm{a}}$ & $47.28 \pm 1.62^{\mathrm{a}}$ & $17.12 \pm 0.75^{\mathrm{a}}$ & $18.91 \pm 1.28^{c}$ & $11.35 \pm 0.63^{\mathrm{a}}$ & $8.63 \pm 0.42^{\mathrm{a}}$ & $5.13 \pm 0.13^{c}$ & $0.25 \pm 0.08^{\mathrm{a}}$ & $4.90 \pm 0.30^{a}$ \\
\hline
\end{tabular}

Values represent the mean \pm standard deviation; $n=3$

$a, b, c$ Means in a column with different superscripts were significantly different $(p \leq 0.05)$

TPC = Total phenolic contents; DPPH = Diphenyl picryl hydrazine; TFC = Total flavonoids contents; TSS = Total soluble solids 
in $\mathrm{T}_{3}$. The incorporation of ZRDP in ZHT influenced the color tonality in the term of $\mathrm{L}^{*}$ value, $\mathrm{a}^{*}$ value and $\mathrm{b}^{*}$ value. $L^{*}$ value was significantly $(p \leq 0.05)$ decreased for $\mathrm{T}_{3}$ samples. In contrast, $\mathrm{a}^{*}$ value and $\mathrm{b}^{*}$ value was significantly $(p \leq 0.05)$ increased for $\mathrm{T}_{3}$ samples when compared with $\mathrm{T}_{1}$ and $\mathrm{T}_{2} . \mathrm{T}_{3}$ samples showed lower $\mathrm{pH}$ $(5.13 \pm 0.13)$ and higher acidity $(0.25 \pm 0.08)$ values than $\mathrm{T}_{1}(5.64 \pm 0.25,0.17 \pm 0.05)$ and $\mathrm{T}_{2}(5.42 \pm 0.21,0.21 \pm$ 0.06). Similarly, an increasing trend in TSS contents was observed with an increase in supplementation of ZRDP in ZHT boiling water. The results of organoleptic evaluation point out the differences between ZHT samples acceptability. Figure 1 indicated that the gradual increase in ZRDP concentration in boiling water affected the sensory characteristics of ZHT samples. The sensory attributes color and flavor obtained higher scores as compared to aroma. Overall, average sensory scores assigned to color, flavor, aroma and overall acceptability attributes varied in a quite narrow range for all ZHT samples. The lowest evaluation scores were recorded for $\mathrm{T}_{3}$ samples.

Various studies support the findings of present research regarding the physico-chemical composition of ZHT samples. TPC in hydroethanolic extract of $\mathrm{Cur}$ cuma zedoaria was found to be $34.45 \pm 1.9$ expressed as $\mathrm{mg} / \mathrm{g}$ equivalent of gallic acid [33]. Curcuma longa and Curcuma aromatica exhibited similar levels of TPC, whereas Curcuma zedoaria showed slightly lower concentration [34]. Antioxidant properties have been found in Curcuma zedoaria. The aqueous extract of fresh and dry Curcuma zedoaria rhizome exhibited DPPH radical scavenging activity in the range of $39-41 \%$ which is very similar to values reported in the present study [35]. In vitro antioxidant activity, $\mathrm{IC}_{50}$ value for zedoary hydroethanolic extract was found to be $930 \pm 16.35$ for DPPH method [33]. Similarly, the concentration of 100 microg/
$\mathrm{mL}$ of water extract of rhizome part of the zedoary plant material exhibited $98.95 \%$ inhibition of DPPH free radicals. DPPH free radical scavenging activity of solvent extracts were high in the order of ethanol, ethylacetate, ether, water, and hexane fractions, Curcuma longa showed greater DPPH free radical scavenging activity than those of the Curcuma aromatic and Curcuma zedoaria [34]. The antioxidant activity of n-hexane, nbutanol and aqueous Curcuma zedoaria soluble fractions was found very less as compared to chloroform and ethyl acetate soluble fractions [36]. The presence of bioactive compounds in solvent extract shows potent antioxidant activity in product [37]. The key role of phenolic compounds as scavengers of free radicals is emphasized in several reports [38, 39]. It has been observed that the phenolic compounds are very important plant constituents because of their scavenging ability due to their hydroxyl groups [40]. The hydroethanolic extract of Curcuma zedoaria rhizome showed antioxidant activity which demonstrates only the presence of the alkaloids [33]. Many medicinal plants contain large amounts of antioxidants such as polyphenols which have been widely used as additives to avoid the degradation of foods. Also, polyphenols have an important role in preventing a variety of stress-related diseases because these are closely related to the active oxygen and lipid peroxidation [41]. Phenolic antioxidants are products of secondary metabolism in plants, and the antioxidant activity is mainly due to their redox properties and chemical structure, which can play an important role in chelating transitional metals, inhibiting lipoxygenase and scavenging free radicals [42].

The main active constituents of zedoary rhizomes are considered coloring matters (curcumin, demethoxycurcumin and bis-demethoxycurcumin) and volatile oil (turmerone, arturmerone and zingiberene) contents [43, 44]

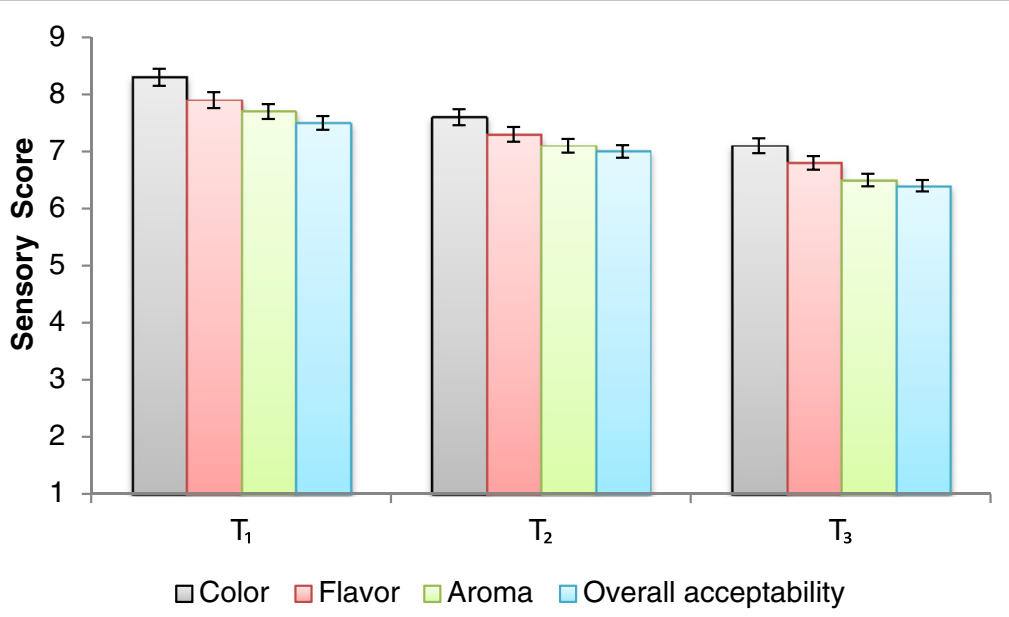

Fig. 1 Organoleptic evaluation of zedoary herbal tea for sensory attributes (color, flavor, aroma and overall acceptability) 
which have widely applications in food industries [45]. The color tonality for $\mathrm{T}_{3}$ indicates that this was the darkest product compared to the $T_{1}$ and $T_{2}$. It was followed by $T_{2}$ and $T_{1}$ being the lightest ones. The boiling of ZRDP enhances the loss of soluble sugars in the cooking water which seems true in case of $\mathrm{T}_{3}$. The presence of more soluble sugars in $\mathrm{T}_{3}$ leads towards the occurrence of Maillard reaction which could cause browning and darkening of the tea samples. The study indicates that processing can be optimized in order to obtain ground Curcuma rhizome with desirable properties to satisfy different markets, such as a product with higher intensity of red for Asian countries and with higher intensity of yellow for other global markets [46]. The change in the $\mathrm{pH}$ and acidity between different ZHT samples might be due to degradation of reducing sugars, formation of acidic components and various byproducts of these acids [47]. Sensory evaluation showed that ZHT $\mathrm{T}_{1}$ and $\mathrm{T}_{2}$ samples were better in appearance, odor and overall acceptability than $\mathrm{T}_{3}$ samples. Inspite of the efforts to collect literature in this regard, very limited relevant literature could be collected. The acceptability analysis of Curcuma longa powder indicates that the samples with bright yellow color were more appealing to eyes as scored 8 in the hedonic scale and the flavor characteristic obtained score 7 from sensory panelists [48]. There were no significant differences among the turmeric: ginger based drinks with respect to color, taste, aroma and general acceptability [49].

\section{ZHT consumption, anthropometric measurements and human plasma lipidic profile}

Results presented in Table 2 indicated that there was slight difference in body weight and BMI values of mild-hypercholestrolemic human subjects due to consumption of ZHT samples for consecutive two months. The body weight of subjects ranged from $78.40 \pm 5.54 \mathrm{~kg}$ to $72.76 \pm 4.67 \mathrm{~kg}$ from day 0 to the end of study. However, the $G_{3}$ showed the more reduction in body weight during efficacy study as compared to $\mathrm{G}_{1}$ and $\mathrm{G}_{2}$. BMI values ranged from $27.74 \pm 2.03$ to $25.98 \pm 1.46$ from day 0 to day 60 . Although, all treatments were effective in reducing $B M I$ value but $T_{3}$ showed more pronounced effect. The mean values of BMI noted for $G_{1}, G_{2}$ and $G_{3}$ were $26.82 \pm 1.72,26.14 \pm 1.34$ and $25.98 \pm 1.46$, respectively at day 60 . Fresh zedoary rhizomes were minced and dried and the resulting meal was given to weanling rats at $400 \mathrm{~g} / \mathrm{kg}$ diet. All the rats lost weight rapidly. This same zedoary meal was given to one-day-old chicks at 100 and $200 \mathrm{~g} / \mathrm{kg}$ diet. All the chicks survived the test period (20 days), but body weight, food intake and efficiency of food conversion decreased with increase in the level of zedoary meal in the diet [50] which support the results found in the present study regarding the loss in body weight after consumption of ZHT. The data collected from ZHT consumers showed that most of the subjects pointed the improved appetite and digestion while none of volunteers feel hyperacidity and gastric pain after taking the ZHT. The root powder at a dose level of $200 \mathrm{mg} / \mathrm{kg}$ reduced the gastric $\mathrm{pH}$, free acid, total acid and ulcer index significantly which provide justification that the zedoary root is effective in affording protection against hyperacidity and gastric ulcers [51].

The effect of experimental ZHT consumption on plasma lipidic profile of mild-hypercholestrolemic human subjects is shown in Table 3. The results regarding percent change in plasma lipidic profile as a result of intake of different experimental ZHT samples have been illustrated in Fig. 2. The results showed that TC, LDLcholesterol and TG was decreased significantly ( $\mathrm{p} \leq 0.05)$ by consuming ZHT samples in experimental subjects at day 60 when compared to the beginning of the study. The decrease in serum TC in human subjects fed on $\mathrm{T}_{1}$, $\mathrm{T}_{2}$ and $\mathrm{T}_{3}$ samples was observed $9 \%, 14 \%$ and $17 \%$ on day 60 , respectively from the reference value at day 0 . There was no significant change in HDL-cholesterol by using $\mathrm{T}_{1}$ at day 60 . However, the consumption of $\mathrm{T}_{3}$ resulted in significant increase (6.8 \%) of HDL-cholesterol after two months. A trend in decrease of serum LDLcholesterol (5.6\%) and TG (12.5\%) was also observed after consumption of $\mathrm{T}_{3}$ samples at day 60. The ZHT samples consumption was found to reduce the TC and TG effectively in mild-hypercholesterolemic conditions. It was reported that Curcuma zedoaria inhibited

Table 2 Impact of zedoary herbal tea consumption on weight $(\mathrm{kg})$ and body mass index (BMI) of mild-hypercholestrolemic human subjects

\begin{tabular}{|c|c|c|c|c|c|c|}
\hline \multirow{2}{*}{$\begin{array}{l}\text { Analysis } \\
\text { duration }\end{array}$} & \multicolumn{3}{|l|}{ Weight (kg) } & \multicolumn{3}{|c|}{ Body mass index (BMI) } \\
\hline & $\mathrm{G}_{1}$ & $\mathrm{G}_{2}$ & $\mathrm{G}_{3}$ & $\overline{\mathrm{G}_{1}}$ & $\mathrm{G}_{2}$ & $\mathrm{G}_{3}$ \\
\hline 0 day & $78.40 \pm 5.54^{a}$ & $76.56 \pm 5.87^{a}$ & $75.61 \pm 6.20^{a}$ & $27.74 \pm 2.03^{a}$ & $27.06 \pm 1.95^{a}$ & $26.92 \pm 1.54^{a}$ \\
\hline 30 days & $77.12 \pm 4.86^{\mathrm{a}}$ & $75.23 \pm 5.15^{a}$ & $74.30 \pm 5.21^{\mathrm{a}}$ & $27.36 \pm 1.97^{\mathrm{a}}$ & $26.78 \pm 1.55^{\mathrm{a}}$ & $26.24 \pm 1.29^{a}$ \\
\hline 60 days & $75.95 \pm 4.32^{b}$ & $73.75 \pm 4.46^{\mathrm{b}}$ & $72.76 \pm 4.67^{b}$ & $26.82 \pm 1.72^{\mathrm{a}}$ & $26.14 \pm 1.34^{\mathrm{a}}$ & $25.98 \pm 1.46^{a}$ \\
\hline
\end{tabular}

Values represent the mean \pm standard deviation; $n=3$

${ }^{a, b}$ Means in a column with different superscripts were significantly different $(p \leq 0.05)$

$G_{1}=$ Provided $T_{1}$ Diet $G_{2}=$ Provided $T_{2}$ Diet $G_{3}=$ Provided $T_{3}$ Diet 
Table 3 Effect of zedoary herbal tea on serum lipid parameters in mild-hypercholesterolemic human subjects

\begin{tabular}{|c|c|c|c|c|}
\hline \multirow[t]{2}{*}{ Serum parameter } & \multirow[t]{2}{*}{ Treatment } & \multicolumn{3}{|l|}{ Analysis period } \\
\hline & & 0 day & 30 days & 60 days \\
\hline \multirow[t]{3}{*}{ Total cholesterol (mg/dL) } & $\mathrm{G}_{1}$ & $218.42 \pm 3.16^{\mathrm{a}}$ & $207.40 \pm 2.94^{b}$ & $198.60 \pm 2.53^{c}$ \\
\hline & $\mathrm{G}_{2}$ & $222.2 \pm 3.08^{\mathrm{a}}$ & $204.32 \pm 2.63^{b}$ & $190.92 \pm 2.15^{c}$ \\
\hline & $\mathrm{G}_{3}$ & $225.50 \pm 2.94^{\mathrm{a}}$ & $202.70 \pm 2.96^{b}$ & $186.50 \pm 3.55^{c}$ \\
\hline \multirow[t]{3}{*}{ HDL-cholesterol (mg/dL) } & $\mathrm{G}_{1}$ & $48.26 \pm 2.12^{a}$ & $49.22 \pm 2.25^{\mathrm{a}}$ & $49.68 \pm 2.44^{a}$ \\
\hline & $\mathrm{G}_{2}$ & $47.5 \pm 2.24^{\mathrm{a}}$ & $48.93 \pm 2.35^{\mathrm{a}}$ & $49.87 \pm 2.57^{\mathrm{a}}$ \\
\hline & $G_{3}$ & $49.78 \pm 2.1^{c}$ & $51.87 \pm 2.75^{b}$ & $53.16 \pm 2.22^{\mathrm{a}}$ \\
\hline \multirow[t]{3}{*}{ LDL-cholesterol (mg/dL) } & $\mathrm{G}_{1}$ & $116.32 \pm 3.11^{\mathrm{a}}$ & $113.41 \pm 2.65^{b}$ & $111.55 \pm 3.15^{b}$ \\
\hline & $\mathrm{G}_{2}$ & $119.18 \pm 2.28^{a}$ & $115.60 \pm 2.12^{b}$ & $113.93 \pm 2.97^{b}$ \\
\hline & $\mathrm{G}_{3}$ & $118.45 \pm 2.76^{\mathrm{a}}$ & $114.54 \pm 2.14^{b}$ & $111.81 \pm 1.95^{\mathrm{c}}$ \\
\hline \multirow[t]{3}{*}{ Triglycerides (mg/dL) } & $\mathrm{G}_{1}$ & $160.38 \pm 3.44^{\mathrm{a}}$ & $150.75 \pm 3.54^{b}$ & $148.35 \pm 2.61^{b}$ \\
\hline & $\mathrm{G}_{2}$ & $164.21 \pm 3.17^{\mathrm{a}}$ & $152.62 \pm 2.26^{b}$ & $149.10 \pm 3.12^{b}$ \\
\hline & $\mathrm{G}_{3}$ & $168.70 \pm 2.92^{\mathrm{a}}$ & $154.69 \pm 2.78^{b}$ & $147.61 \pm 2.56^{c}$ \\
\hline \multirow[t]{3}{*}{ AST (U/L) } & $\mathrm{G}_{1}$ & $34.88 \pm 1.23^{\mathrm{a}}$ & $34.15 \pm 1.14^{\mathrm{a}}$ & $33.95 \pm 1.11^{\mathrm{a}}$ \\
\hline & $\mathrm{G}_{2}$ & $34.72 \pm 1.17^{\mathrm{a}}$ & $33.98 \pm 1.10^{a}$ & $33.70 \pm 1.12^{a}$ \\
\hline & $\mathrm{G}_{3}$ & $34.56 \pm 0.92^{\mathrm{a}}$ & $33.75 \pm 1.08^{\mathrm{a}}$ & $33.21 \pm 1.16^{\mathrm{a}}$ \\
\hline \multirow[t]{3}{*}{$\operatorname{ALT}(U / L)$} & $\mathrm{G}_{1}$ & $37.28 \pm 1.41^{\mathrm{a}}$ & $36.87 \pm 1.34^{\mathrm{a}}$ & $36.45 \pm 1.21^{a}$ \\
\hline & $\mathrm{G}_{2}$ & $37.46 \pm 1.27^{a}$ & $36.57 \pm 1.26^{a}$ & $36.10 \pm 1.12^{\mathrm{a}}$ \\
\hline & $\mathrm{G}_{3}$ & $37.72 \pm 1.32^{\mathrm{a}}$ & $36.54 \pm 1.18^{\mathrm{a}}$ & $35.93 \pm 1.06^{\mathrm{a}}$ \\
\hline
\end{tabular}

Values represent the mean \pm standard deviation; $n=3$

$a, b, c$ Means in a row with different superscripts were significantly different $(p \leq 0.05)$

HDL High Density Lipoprotein, LDL Low Density Lipoprotein

AST Aspartate aminotransferase, ALT Alanine aminotransferase

$G_{1}=$ Provided $T_{1}$ Diet $; G_{2}=$ Provided $T_{2}$ Diet $; G_{3}=$ Provided $T_{3}$ Diet

$50.60 \%$ platelet activating factor binding to rabbit platelets at a concentration of $200 \mathrm{mg} / \mathrm{mL}$ [52]. Means depicted in Table 3 for AST showed non-significant differences $(p \geq 0.05)$ from $34.88 \pm 1.23$ to $33.95 \pm 1.11 \mathrm{U} / \mathrm{L}$ and $34.56 \pm 0.92$ to $33.21 \pm 1.16 \mathrm{U} / \mathrm{L}$ at initiation and termination of study in $G_{1}$ and $G_{3}$, respectively. Similarly, ALT values were recorded ranging from $37.28 \pm 1.41$ to
$36.45 \pm 1.21 \mathrm{U} / \mathrm{L}$ and $37.72 \pm 1.32$ to $35.93 \pm 1.06 \mathrm{U} / \mathrm{L}$ at 0 and 60 days in respective mild-hypercholesterolemic subject groups, correspondingly. It is worth mentioning that overall means of AST and ALT remained in safe range predicting proper liver functioning and indicating that the ZHT consumption is friendly for mildhypercholesterolemic subjects. The survey of 32 books

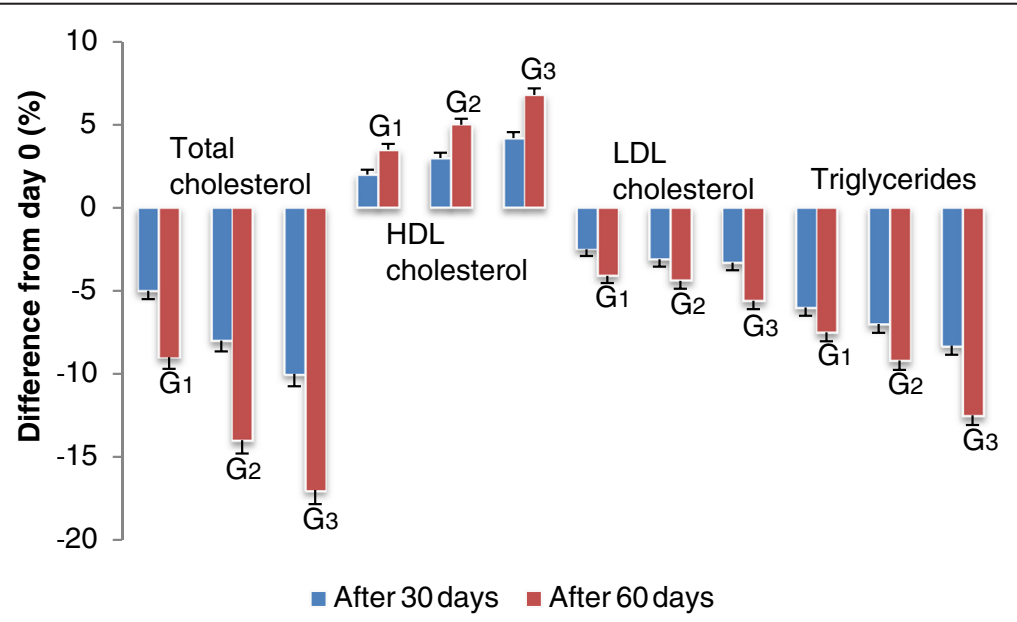

Fig. 2 Effect of zedoary herbal tea consumption on percent change in serum lipid profile in mild-hypercholesterolemic human subjects 
published in Brazil between 1998 and 2008, resulting in a list of 85 medicinal plants species belonging to $53 \mathrm{fam}$ ilies including Curcuma zedoaria (Zingiberaceae) indicates the consumption of these plants for the possible treatment of hyperlipidemia, hypercholesterolemia and/ or atherosclerosis [53]. Twelve Thai selected plants including Curcuma zedoaria supplemented as spices and ingredients in various types of Thai foods possessed multiple sites of action that were possibly responsible for their cholesterol-lowering effect in the in-vivo model [54]. The zedoary extract at a dose of $200-400 \mathrm{mg} / \mathrm{kg} \mathrm{b} /$ $\mathrm{w}$ was found to be effective in reducing TC levels (17.1 \%-19.65 \%) after 12 days of pre-treatment which indicates antihyperlipidemic activity. However, no significant changes were seen on LDL-cholesterol, VLDL and HDL-cholesterol levels [33]. The supplementation and oral administration of Curcuma zedoaria in male Wistar rats diet resulted in low levels of total lipids, TC, TG, phospholipids and thiobarbituric acid reactive substances (TBARS) in the liver which suggests that Curcuma zedoaria may have recuperative effects for hypercholesterolemia [55]. Herbal preparations of Curcuma zedoaria lowered the levels of serum TC, phospholipids and TG to varying extents in Triton-induced hyperlipidemic rats [56]. Administration of dried leaf powder leads towards decrease in levels of serum glucose, TC, TG and LDL-cholesterol levels in Wistar rats [57]. Curcuma's cholesterol-lowering actions include interfering with intestinal cholesterol uptake, increasing the conversion of cholesterol into bile acids and increasing the excretion of bile acids via its choleretic effects [58]. Among the plant extracts, Curcuma showed potent antioxidant activity which might be due to the presence of high phenolic and flavonol contents such as curcumin which help to reduce the blood cholesterol, prevents LDL peroxidation, inhibits platelet aggregation and suppress thrombosis [59]. Metabolic risk factors, particularly serum concentration of TGs and HDL-cholesterol have been reported to improve most with weight loss in men [60] which seems true in the present research study as slight change in body weight of ZHT consumers was related with beneficial effect on dyslipidemia. The medicinal plants such like zedoary may be broadly applied in modern phytotherapy once they have been clinically and experimentally tested [61]. The natural extracts of Curcuma zedoaria can be explained in the field of pharmaceutical areas for their uses in modern health care as phytoprotectants [62]. The rhizomes of the family Zingiberaceae are a vegetable widely used in many Asian countries and their medicinal functions have been broadly discussed and accepted in many traditional recipes [63]. Therefore, this study is a positive demonstration of the utility of zedoary for food and medicinal uses.

\section{Conclusions}

The results of the present study conclude that the strong phenolic contents and radical scavenging activity of zedoary rhizome have protective role against dysfunction of metabolic syndrome. The information from the present study can be applied for the industrial production of zedoary supplemented food products. Further studies are needed to investigate the storage stability of zedoary supplemented products and their role as therapeutic agent in preventing or slowing down the progress of ageing and age associated oxidative stress related degenerative diseases in women subjects with and without allied conditions of menstruation, pregnancy or breastfeeding stage. Randomized double blind placebo control studies involving zedoary consumption should be considered for healthy and diabetic subjects in future. It is also proposed that patients on blood-thinning medications or blood pressure medications should also speak with a health care provider before taking zedoary.

\section{Competing interests \\ The authors declare that they have no competing interests.}

\section{Authors' contributions}

ST conceptualized and performed the study; ZM provided the technical assistance and guided in the data collection; MI and NA helped to analyze the data and drafting the manuscript. All authors read and approved the final manuscript.

\section{Acknowledgement}

The authors are highly obliged to the Post Harvest Research Center, Ayub Agricultural Research Institute and National Institute of Food Science and Technology, University of Agriculture, Faisalabad, Pakistan for use of laboratory equipment and supplies to complete this research work. Authors thanks the Library Department, Government College University Faisalabad (GCUF) and IT Department, Higher Education Commission (HEC) for access to journals, books and valuable database.

\section{Author details}

${ }^{1}$ Department of Food Science, Nutrition and Home Economics, Government College University, Faisalabad, Pakistan. ${ }^{2}$ Institute of Home and Food

Sciences, Faculty of Science and Technology, Government College University, Faisalabad, Pakistan.

Received: 16 January 2016 Accepted: 23 February 2016

Published online: 27 February 2016

\section{References}

1. Dias DA, Urban S, Roessner U. A historical overview of natural products in drug discovery. Metabolites. 2012;2:303-36

2. Babu KN, Sabu M, Shiva KN, Divakaran M, Ravindran PN. Ginger. In: Singh RJ, editor. Genetic Resources, Chromosome Engineering, and Crop Improvement: Medicinal Plants. Boca Raton: CRC Press, Taylor and Francis Group; 2011. p. 393-450.

3. Wilson B, Abraham G, Manju VS, Mathew M, Vimala B, Sundaresan S, Nambisan B. Antimicrobial activity of Curcuma zedoaria and Curcuma malabarica tubers. J Ethnopharmacol. 2005:99:147-51.

4. Makabe H, Maru N, Kuwabara A, Kamo T, Hirota M. Anti-inflammatory sesquiterpenes from Curcuma zedoaria. Nat Prod Res. 2006;20:680-85.

5. Lobo R, Prabhu KS, Shirwaikar A, Shirwaikar A. Curcuma zedoaria Rosc. (white turmeric): a review of its chemical, pharmacological and ethnomedicinal properties. J Pharm Pharmacol. 2009;61:13-21.

6. Gao XF, Li QL, Li HL, Zhang HY, Su JY, Wang B, Liu P, Zhang AQ. Extracts from Curcuma zedoaria inhibit proliferation of human breast cancer cell 
MDA-MB-231 in vitro. Evid Based Complement Alternat Med. 2014;2014: 730678.

7. Ullah HM, Zaman S, Juhara F, Akter L, Tareq SM, Masum EH, Bhattacharjee R. Evaluation of antinociceptive, in-vivo \& in-vitro anti-inflammatory activity of ethanolic extract of Curcuma zedoaria rhizome. BMC Complement Altern Med. 2014;14:346.

8. Duke AJ, Bogenschutz Godwin MJ, duCellier J, Duke PGK. CRC Handbook of Medicinal Spices. Boca Raton: CRC Press; 2003. p. 148-50.

9. Singh P, Singh S, Kapoor IPS, Singh G, Isidorov V, Szczepaniak L. Chemical composition and antioxidant activities of essential oil and oleoresins from Curcuma zedoaria rhizomes, part-74. Food Biosci. 2013;3:42-8.

10. Liu Y, Roy SS, Nebie RH, Zhang Y, Nair MG. Functional food quality of Curcuma caesia, Curcuma zedoaria and Curcuma aeruginosa endemic to Northeastern India. Plant Foods Hum Nutr. 2013;68:72-7.

11. AACC. Approved Methods of American Association of Cereal Chemists. 10th ed. St. Paul, Minnesota, USA: The American Association of Cereal Chemists, Inc;; 2000

12. AOAC. Official Methods of Analysis. 18th ed. VA, USA: The Association of the Official Analytical Chemists. Arlington; 2006.

13. Van Soest PJ, Robertson JB, Lewis BA. Methods for dietary fiber, neutral detergent fiber, and nonstarch polysaccharides in relation to animal nutrition. J Dairy Sci. 1991;74:3583-97.

14. Singleton VL, Orthofer R, Lamuela RRM. Analysis of total phenols and other oxidation substrates and antioxidants by means of Folin-Ciocalteu reagent. Methods in Enzym. 1999;299:152-78.

15. Mensor LL, Mennezes FS, Leitao GG, Reis AS, Santos TC, Coube CS, Leitao SG. Screening of Brazilian plant extacts for antioxidant activity by the use of DPPH free radical method. Phytotherapy Res. 2001;15:127-30.

16. Ordonez AAL, Gomez JD, Vattuone MA, Isla MI. Antioxidant activities of Sechium edule (Jacq.) Swart extracts. Food Chem. 2006;97:452-58.

17. Rocha AMCN, Morais AMMB. Shelf life of minimally processed apple (CV Jonagored) determined by colour changes. Food Cont. 2003;14:13-20.

18. Meilgaard MC, Civille GV, Carr BT. Sensory Evaluation Techniques. 4th ed. Boca Raton: CRC Press; 2007. p. 464.

19. Allain CC, Poon LS, Chan CSG, Richmond W, Fu P. Enzymatic determination of total serum cholesterol. Clin Chem. 1974;20:470-75.

20. Assmann G. HDL-cholesterol precipitant. Randox Labs. Ltd. Crumlin Co. Antrim, N. Ireland. Internist. 1979:20:559-64.

21. McNamara JR, Cohn JS, Wilson PW, Schaefer EJ. Calculated values for lowdensity lipoprotein cholesterol in the assessment of lipid abnormalities and coronary disease risk. Clin Chem. 1990;36:36-42.

22. Annoni G, Botasso BM, Ciaci D, Donato MF, Tripodi A. Liquid triglycerides (GOP-PAP). Med. Diagnostic Italy Lab. J Res Lab Med. 1982;9:115-16.

23. Basuny AM, Gaafar AM, Arafat SM. Tomato lycopene is a natural antioxidant and can alleviate hypercholesterolemia. Afr J Biotechnol. 2009;8:6627-33.

24. Steel RGD, Torrie JH, Dickey D. Principles and Procedures of Statistics, A Biometrical Approach. 3rd ed. New York: McGraw Hill Book Co Inc, USA; 1997

25. Skornickova J, Rehse T, Sabu M. Other economically important Curcuma species. In: Ravindran PN, Babu KN, Sivaraman K, editors. Turmeric The Genus Curcuma. Boca Raton: CRC Press, Taylor and Francis Group; 2007. p. 451-68.

26. Subhadhirasakul S, Wongvarodom S, Ovatlarnporn C. The content of active constituents of stored sliced and powdered preparations of turmeric rhizomes and zedoary (bulb and finger) rhizomes. Songklanakarin J Sci Technol. 2007;29:1527-36.

27. Srivastava NR, Lal BR, Kumar SV, Dhirendra K. Physicochemical and phytochemical investigation of three different species of curcuma rhizome. Int Res J Pharm. 2013;4:163-66

28. Rahman MM, Gheyasuddin S. A study on the chemical composition of shot rhizome (Curcuma zedoaria) and commercial shoti barley. Bangladesh J Agri Sci. 1986:13:21-4.

29. Srivastava S, Mehrotra S, Rawat AKS. Pharmacognostic evaluation of the rhizomes of Curcuma zedoaria Rosc. Pharmacognosy J. 2011;3:20-6.

30. He ZL, Yang XE, Stoffella PJ. Trace elements in agroecosystems and impacts on the environment. J Trace Elem Med Biol. 2005;19:125-40.

31. Liu H, Probst A, Liao B. Metal contamination of soils and crops affected by the Chenzhou lead/zinc mine spill (Hunan, China). Sci Total Environ. 2005; 339:153-66.

32. Tian RT, Xie PS, Liu HP. Evaluation of traditional Chinese herbal medicine: Chaihu (Bupleuri Radix) by both high performance liquid chromatographic and high-performance thin-layer chromatographic fingerprint and chemometric analysis. J Chromatogr A. 2009;1216:2150-55.

33. Srividya AR, Dhanabal SP, Yadav AK, Kumar SMN, Vishnuvarthan VJ. Phytopreventive anti-hyperlipidemic activity of Curcuma zedoaria. Bulletin Pharm Res. 2012;2:22-5.

34. Kim HJ, Lee JW, Kim YD. Antimicrobial activity and antioxidant effect of Curcuma longa, Curcuma aromatica and Curcuma zedoaria. Korean J Food Preserv. 2011;18:219-25.

35. Sumathi S, Iswariya GT, Sivaprabha B, Dharani B, Radha P, Padma PR. Comparative study of radical scavenging activity and phytochemical analysis of fresh and dry rhizomes of Curcuma zedoaria. Int J Pharm Sci Res. 2013;4:1069-73.

36. Riaz A, Abbasi MA, Aziz-ur-Rehman, Shahzadi T, Qureshi MZ, Khan KM. Antioxidant activity and radical scavenging effects of various fractions from Curcuma zedoaria. Asian J Pharm Bio Res. 2011:1:525-33.

37. Himaja M, Anand R, Ramana MV, Anand M, Karigar A. Phytochemical screening and antioxidant activity of rhizome part of Curcuma zedoaria. Int J Res Ayurveda pharm. 2010;1:414-17.

38. Madsen HL, Nielsen BR, Bertelsen G, Skibsted LH. Screening of antioxidative activity of spices. A comparison between assays based on ESR spin trapping and electrochemical measurement of oxygen consumption. Food Chem. 1996:57:331-37

39. Moller JKS, Madsen HL, Altonen T, Skibsted LH. Dittany (Origanum dictamnus) as a source of water-extractable antioxidants. Food Chem. 1999; 64:215-19.

40. Hatano T, Edamatsu R, Mori A, Fujita Y, Yasuhara E. Effect of interaction of tannins with co-existing substances. VI. Effects of tannins and related polyphenols on superoxide anion radical and on DPPH radical. J Chem Pharm Bull. 1989;37:2016-21.

41. Noguchi N, Niki E. Chemistry of active oxygen species and antioxidants. In: Papas AM, editor. Antioxidant Status, Diet, Nutrition and Health. Boca Raton: CRC Press; 1999. p. 3-20.

42. Decker EA. Phenolics: prooxidants or antioxidants? Nutr Rev. 1997;55:396-98.

43. Martins AP, Salqueiro L, Goncalves MJ, Cunha AP, Vila R, Caniqueral S, et al. Essential oil composition and antimicrobial activity of three Zingiberaceae from S. Tome e Principe. Planta Medica. 2001;67:580-84.

44. Mau JL, Lai EYC, Wang NP, Chen CC, Chang CH, Chyau CC. Composition and antioxidant activity of the essential oil from Curcuma zedoaria. Food Chem. 2003;82:583-91.

45. Souza CRA, Osme SF, Gloria MBA. Stability of curcuminoids pigments in model systems. J Food Process Preserv. 1997;21:353-63.

46. Bambirra MLA, Junqueira RG, Glória MBA. Influence of post harvest processing conditions on yield and quality of ground turmeric (Curcuma longa L.). Braz Arch Biol Technol. 2002;45:423-29.

47. Andrews LS, Godshall MA, Moore S. Sucrose degradation under model processing conditions. Journal Food Sci. 2002;67:1621-24.

48. Chittrarasarayan S, Ghadevaru S, Manimehalai N, Athmaselvi KA. Quality assessment of processed Curcuma longa (turmeric) powder for microbial contamination and physico-chemical properties. The Int J Sci Technol. 2015: 3:101-06.

49. Ekeledo EN, Omodamiro RM, Oti E. Development and evaluation of turmeric: Ginger based pineapple drinks and food flavourings. Asian J Plant Sci Res. 2013:3:139-41.

50. Latif MA, Morris TR, Miah AH, Hewitt D, Ford JE. Toxicity of shoti (Indian arrowroot: (urcuma zedoaria) for rats and chick. Br J Nutr. 1979:41:57-63.

51. Gupta RP, Md M, Eranna D, Setty R. Evaluation of antiulcer effect of root of Curcuma zedoaria in rats. Ind J of Trad know. 2003:2:375-7.

52. Han BH, Yang HO, Kang YH, Han YN. Screening of the inhibitory effect of herbal medicines on the platelet activating factor (PAF) binding: 35 selected herbal medicines based on folk medicinal informations. Yakhak Hoeji. 1995; 39:10-3.

53. Pizziolo VR, Brasileiro BG, Oliveira TT, Nagem TJ. Plants with possible hypolipidemic activity: a review of books published in Brazil between 1998 and 2008. Rev Bras PI Med Botucatu. 2011:13:98-109.

54. Duangjai A, Ingkaninan K, Limpeanchob N. Potential mechanisms of hypocholesterolaemic effect of Thai spices/dietary extracts. Nat Prod Res. 2011;25:341-52

55. Uechi S, Kuniyoshi M, Ogura G, Kawashima Y, Nakada T, Tako M, Hongo F. Effect of oral administration of Gajyutsu (Curcuma zedoarla Roscoe.) on serum and hepatic lipids concentration in rats fed a high cholesterol diet. The West Japan J Animal Sci. 2003:46:29-34. 
56. Kar A, Chander R, Mathur SK, Chaudhary BK, Khanna AK, Rastogi AK. Lipid lowering and antioxidant activities of some herbal preparations. Ethnobotany. 2000;12:86-90.

57. Ahmed R, Moushumi SJ, Ahmed H, Ali M, Haq WM, Jahan R, Rahmatullah M. Serum glucose and lipid profiles in rats following administration of Sonneratia caseolaris (L.) Engl. (Sonneratiaceae) leaf powder in diet. Adv Nat Appl Sci. 2010;4:171-73.

58. Khare CP. Indian Medicinal Plants: An Illustrated Dictionary. New York: Springer Science Publishers; 2008. p. 188-9.

59. Srividya AR, Dhanabal SP, Kumar MNS, Vishnuvarthan VJ. Relationship between the Curcumin and antioxidant activity in Curcuma aromatica and Curcuma zedoaria rhizomes. J Free Radicals Antioxidants Photon. 2013;139: 186-98.

60. Wing RR, Jeffery RW, Burton LR, Thorson C, Kuller LH, Folsom AR. Change in waist- hip ratio with weight loss and its association with change in cardiovascular risk factors. Am J Clin Nutr. 1992;55:1086-92.

61. Alakbarov FU. Medicinal plants used in Medieval Azerbaijan phytotherapy. J Herb Pharmacother. 2001;1:35-49.

62. Nahak G, Sahu RK. Evaluation of antioxidant activity in ethanolic extracts of five curcuma species. Int Res J Pharm. 2011;2:243-48.

63. Chen IN, Chang CC, Ng CC, Wang CY, Shyu YT, Chang TL. Antioxidant and antimicrobial activity of Zingiberaceae plants in Taiwan. Plant Foods Hum Nutr. 2008;63:15-20

\section{Submit your next manuscript to BioMed Central} and we will help you at every step:

- We accept pre-submission inquiries

- Our selector tool helps you to find the most relevant journal

- We provide round the clock customer support

- Convenient online submission

- Thorough peer review

- Inclusion in PubMed and all major indexing services

- Maximum visibility for your research

Submit your manuscript at www.biomedcentral.com/submit 